\title{
GENTRIFIKASI DAN PERGOLAKAN LAHAN DI KELURAHAN TANJUNG TONGAH KECAMATAN SIANTAR MARTOBA KOTA PEMATANGSIANTAR
}

\author{
Dwi Anggraeni , Teuku Kemal Fasya, Abdullah Akhyar Nasution \\ Program Studi Antropologi \\ Fakultas Ilmu Sosial dan Ilmu Politik, Universitas Malikussaleh \\ Aceh-Indonesia
}

Korespondensi: dwianggraeni0411gmail.com

\begin{abstract}
This article has the theme of land conversion or gentrification that occurred in Tanjung Tongah Village, Martoba District, Pematangsiantar City. In depth, this study will observe and analyze the background of the gentrification process at the research location. This research uses qualitative social methods that are descriptive in nature with observation techniques, in-depth interviews, documentation study and literature study. The results showed that there are several factors behind the occurrence of gentrification in Tanjung Tongah Village, including unclear land ownership status by the community, factors of urban development and urbanization as well as factors of economic turmoil experienced by land owners.
\end{abstract}

Abstrak: Artikel ini bertema alih fungsi lahan atau gentrifikasi yang terjadi di kelurahan Tanjung Tongah, Kecamatan Martoba, Kota Pematangsiantar. Secara mendalam penelitian ini akan mengamati dan menganalisis latarbelakang terjadinya proses gentrifikasi di lokasi penelitian. Penelitian ini menggunakan metode sosial kualitatif yang bersifat deskriftif dengan teknik observasi, wawancara mendalam, studi dokumentasi dan studi kepustakaan. Hasil penelitian menunjukkan bahwa ada beberapa hal yang melatarbelakangi terjadinya gentrifikasi di Kelurahan Tanjung Tongah, di antaranya status kepemilikan lahan yang tidak jelas oleh masyarakat, faktor pembangunan kota dan urbanisasi serta faktor gejolak ekonomi yang dialami oleh masyarakat pemilik lahan.

Kata Kunci: Gentrifikasi, Alih Fungsi Lahan, Kepemilikan Lahan, Antropologi Perkotaan 
Aceh Anthropological Journal, Vol. 3, No. 2, hlm: 144-156, Oktober 2019

\section{A. Pendahuluan}

Perencanaan spasial di Indonesia bersandar pada pendekatan Rational Comprehensive Planning (RCP), yang cenderung mengasumsikan bahwa seorang perencana merupakan pihak dengan kepemilikan ilmu yang kompeten sehingga mampu merencanakan apa yang sesuai untuk masyarakat. Namun, meskipun sudah mempertimbangkan prinsip-prinsip pembangunan berkelanjutan dalam melakukan proses perencanaan, pendekatan ini masih dianggap memiliki kekurangan. Salah satu kelemahan RCP adalah bahwa perencanaan disusun oleh para ahli dengan asumsi bahwa apa yang mereka rencanakan sesuai dan yang terbaik untuk masyarakat, akan tetapi masyarakat sendiri tidak berfungsi sebagaimana dipersepsikan oleh perencana.

Tren untuk membangun perkotaan dengan prinsip pembangunan berkelanjutan mempertimbangkan aspek lingkungan, sosial dan ekonomi. Dengan banyaknya model perencanaan pembangunan yang berbasis modern dengan prinsip berkelanjutan tentunya tidak hanya membawa dampak positif bagi suatu wilayah, melainkan juga bisa membawa dampak negatif pada wilayah tertentu. Salah satu dari banyaknya fenomena pembangunan yang masih menjadi dilema bagi masyarakat terhadap perencanaan pembangunan adalah dengan adanya fenomena Gentrifikasi.

Secara eksplisit gentrifikasi diartikan sebagai suatu fenomena yang menandakan perubahan sosial budaya yang tercipta akibat penduduk kaya membeli properti perumahan di permukiman yang kurang makmur. Laju perkembangan mengenai g entrifikasi di Indonesia sendiri sudah mulai muncul di beberapa penulisan mengenai jurnal Penataan Ruang, Pembangunan Wilayah Kota dan sebagainya, dan walau sebenarnya belum terlalu banyak orang tau mengenai konsep yang terbilang masih baru ini. Fenomena ini pun sudah dari lama kemunculan dan dampaknya dirasakan, namun hanya saja kita tidak pernah menyadari bahwa ternyata hal ini bisa jadi sangat berdampak untuk keberlangsungan pembangunan di masa mendatang, terlebih pengaruh yang dibawa terhadap masyarakat erat kaitannya dengan mobilitas masyarakat lokal 
yang tergentrifikasi baik dari segi Ekonomi, Sosial dan Kebudayaannya. Tentunya menjadi penting dan menarik apabila masalah ini dikaji lewat kacamata Antropolog.

Berdasarkan definisi tersebut, dapat disimpulkan bahwa fenomena gentrifikasi muncul akibat adanya proses peningkatan suatu kawasan yang telah sukses menarik perhatian masyarakat golongan kaya, dan menciptakan kedinamisan wilayah dimana hal tersebut akan menstimulasi kenaikan harga properti yang harganya diluar jangkauan masyarakat semula, sehingga masyarakat menjadi rentan untuk terusir dari kawasan huniannya. Gentrifikasi jelas merupakan sebuah fenomena yang mengancam eksistensi suatu masyarakat karena akibat-akibat dari naik kelasnya sebuah kawasan menjadi kawasan yang bernilai tinggi, dimana masyarakat menjadi tidak sanggup untuk menyesuaikan diri dengan kawasan tersebut.

Salah satu wilayah yang juga mengalami fenomena gentrifikasi yang sekaligus menjadi lokasi studi kasus peneliti adalah di Kelurahan Tanjung Tongah, Kecamatan Siantar Martoba, Kota Pematangsiantar Provinsi Sumatera Utara. Pematangsiantar sendiri merupakan kota ke dua terbesar setelah ibu kota Sumatera Utara yaitu kota Medan. Kota ini memiliki luas wilayah 79,971 km2 dengan jumlah penduduk sebanyak 251,516 jiwa, data statistik kependudukan menunjukkan bahwa peningkatan penduduk di kota ini terhitung mulai dari tahun 2010-2017 meningkat hingga 25\%. Pertumbuhan penduduk di kota ini tentu mempengaruhi pola pembangunan terutama dari segi permukiman.

Penelitian ini tentunya akan menarik apabila di telusuri lebih mendalam, melihat kondisi yang ada di lapangan di mana tentunya tidak hanya terjadi di pinggiran kota Pematangsiantar saja, melainkan tanpa kita sadari fenomena Gentrifikasi sudah mulai mewabah di mana-mana, dan apabila tidak dilakukan penanganan tentunya ini akan terus menerus menjadi dilema pada masyarakat dalam menempatkan diri mereka di suatu lingkungan yang mereka tempati.

Fenomena gentrifikasi dapat kita lihat sebagai objek studi dari antropologi perkotaan. Antropologi Perkotaan adalah spesialisasi antropologi dalam melihat problematika kehidupan manusia sebagai kesatuan society (masyarakat) maupun community di wilayah perkotaan. Problematika perkotaan dimaksud merupakan 
permasalahan yang muncul dan berkembang dalam kehidupan masyarakat kota itu sendiri dan yang membedakannya dengan masyarakat pedesaan. Problematika Antropologi Perkotaan tidak semata-mata hanya melihat perbandingan yang terjadi antara kota dan desa berdasarkan karekter fisik maupun budayanya.

Antropologi hadir untuk melihat fenomena ini selama proses peralihan fungsi lahan di Kecamatan Siantar Martoba, Kelurahan Tanjung Tongah. Dengan bahasa lain fenomena semacam ini disebut sebagai fenomena gentrifikasi, gejolak beralih fungsinya lahan pertanian di atas bergantinya menjadi lahan perumahan elit dengan melihat keterlibatan yang di jalin antara pihak-pihak yang terlibat baik itu pengembang (developer), pemerintah, agen dan masyarakat yang ikut serta dalam merasakan perubahan yang dibawa oleh fenomena tersebut.

Gentrifikasi sebagai objek studi tidak saja menjadi fenomena yang seringkali dikaji oleh antropologi, banyak bidang kajian lain yang juga melihat fenomena tersebut. Seperti penelitian I Nyoman Tri Prayoga dengan judul "Keberlangsungan Menetap Penduduk Asli Pada Kawasan di Sekitar Kampus UNDIP Tembalang Sebagai Permukiman Kota Semarang yang Tergentrifikasi". Penelitian ini menjelaskan tentang keberlangsungan hidup para penduduk asli di tengah tekanan datangnya penduduk baru yang lebih mampu. Serta melihat bagaimana persepsi penduduk asli (gentrified) terhadap penduduk pendatang (gentrifier) yang mampu mempengaruhi sikap dan gaya hidup para penduduk asli.

Selain itu, Linda Cristi Corolina juga pernah melihat tentang Implementasi Kebijakan Alih Fungsi Lahan Pertanian Menjadi Kawasan Perumahan. Penelitian Linda memaparkan tentang peningkatan pembangunan kawasan perumahan di Kabupaten Sidoarjo seiring dengan meningkatnnya jumlah penduduk dan kebutuhan akan hunian baru. Untuk itu para pengembang perumahan (developer) kerap memanfaatkan serta mengalihfungsikan lahan pertanian.

Dan yang terakhir studi uyang dilakukan oleh Indra Gumay Febriyanto, dalam penelitian yang berjudul "Aktor Dan Relasi Kekuasaan Dalam Pengelolaan Mangrove Di Kabupaten Pesawaran, Provinsi Lampung, Indonesia". Dia menceritakan tentang terjadinya politisasi lingkungan yang mengakibatkan degradasi lingkungan dan marginalisasi dalam masyarakat lokal. Tujuan dari 
penelitian adalah untuk menguraikan dan menjelaskan aktor dan relasi kekuasaan yang terjadi dalam pengelolaan mangrove. Hasil penelitian menunjukkan bahwa kebijakan pemerintah kabupaten tidak berjalan dengan baik dan efektif ketika pengusaha mampu mengkonversi mangrove menjadi tambak udang intensif. LSM dan masyarakat berupaya menggalang kekuatan untuk mencegah konversi terhadap mangrove yang tersisa, namun belum cukup kuat menghadapi akses pengusaha.

Berdasarkan pendahuluan yang telah penulis uraikan di atas, maka penulis ingin melihat dan mendeskripsikan tentang proses gentrifikasi dan bagaimana gentrifikasi tersebut terjadi di Kelurahan Tanjung Tongah, Kecamatan Martoba, Kota Pematangsiantar.

\section{B. Metode Penelitian}

\section{Pemilihan Lokasi Penelitian}

Penelitian ini dilaksanakan di Kelurahan Tanjung Tongah, Kecamatan Siantar Martoba, Kota Pematangsiantar. Penulis menjadikan Tanjung Tongah sebagai lokasi penelitian karena, (1) wilayah tersebut merupakan daerah dengan lahan kosong pertanian non sawah terbanyak di Pematangsiantar; (2) wilayah tersebut saat ini sudah banyak mengalami pengalihfungsian lahan pertanian menjadi lahan perumahan.

Dari delapan jumlah Kecamatan yang ada di Kota Pematangsiantar, ada dua Kecamatan yang memiliki lahan pertanian bukan sawah yang lebih luas, diantaranya adalah di Kecamatan Siantar Martoba dan Kecamatan Siantar Sitalasari. Pada tahun 2017 luas lahan pertanian bukan sawah yaitu 2.168 ha, kemudian lahan tersebut mengalami penurunan sebesar 26 ha atau 1,19 persen dibandingkan tahun 2016. Penurunan tersebut terjadi paling banyak di Kecamatan Siantar Martoba yang disebabkan oleh beralihnya fungsi lahan menjadi lahan perumahan dan hal tersebut dapat diketahui dari semakin meningkatnya lahan permukiman baru di kecamatan tersebut. 


\section{Pendekatan Penelitian}

Dalam penulisan ini penulis bermaksud mengumpulkan data dengan menggunakan metode pendekatan penelitian kualitatif yang dituliskan dengan menggunakan model penulisan Etnografi. Etnografi, ditinjau secara harfiah berarti tulisan atau laporan tentang suatu suku-bangsa, yang ditulis oleh seorang antropolog atas hasil penelitian lapangan (field work) selama sekian bulan atau sekian tahun. Dalam penelitian ini penulis menggunakan beberapa teknik pengumpulan dan pengolahan data, diantaranya; Observasi, wawancara mendalam, studi literatur dan studi dokumen.

Menurut Moleong, observasi merupakan suatu pengamatan yang dilakukan secara sengaja dan sistematis mengenai fenomena sosial dengan metodologi bagi penggunaan pengamatan yang berfungsi untuk mengoptimalkan kemampuan penulis dari segi motif, kepercayaan, perhatian, prilaku tak sadar, kebiasaan dan sebagainya yang memungkinkan penulis untuk merasakan apa yang dirasakan oleh objek penelitian.

Dalam proses wawancara mendalam, penulis menggunakan tiga kategori informan yang sumberdata bagi penelitian ini, yaitu ;

a. Informan Kunci (Key Informant), yaitu mereka yang mengetahui dan memiliki informasi pokok atau data utama yang diperlukan dalam penelitian. Maka yang menjadi key informant dalam penelitian ini yaitu seorang pengembang perumahan (developer) yang berinteraksi secara langsung dalam proses perubahan suatu kawasan, seorang agen properti yang menjadi penghubung negosiasi antara pemilik lahan dengan developer, beberapa karyawan di Instansi Pemerintahan yaitu BAPPEDA dan BPN selaku yang berperan dalam menanggapi dan memberi izin atas berdirinya perumahan di Kelurahan Tanjung Tongah serta dua orang pemilik lahan yang mempunyai hak atas lahan tersebut.

b. Informan Pendukung (Supporting Informant), yaitu masyarakat yang terlibat secara langsung dalam interaksi sosial yang diteliti maupun pihak-pihak yang membantu peneliti memberi informasi mengenai 
Aceh Anthropological Journal, Vol. 3, No. 2, hlm: 144-156, Oktober 2019

situasi dan lokasi penelitian. Maka yang menjadi informan pendukung dalam penelitian ini adalah Lurah Kelurahan Tanjung Tongah, seorang staf Kecamatan Siantar Martoba, serta empat sampai lima orang masyarakat setempat yang secara langsung merasakan adanya gentrifikasi.

\section{Pembahasan}

\section{Geliat Kemunculan Gentrifikasi di Tanjung Tongah}

Pergolakan lahan yang terjadi di Tanjung Tongah sudah dimulai sejak masa kolonial Belanda dan penjajahan Jepang. Meski pada saat itu pergolakan lahan lebih kepada kepemilikan oleh bangsa asing dengan pribumi. Meski demikian hal tersebut tetap menimbulkan konflik yang cukup panjang.

Seperti penjelasan salah satu narasumber, bahwa pergolakan terkait lahan di Tanjung Tongah memang sudah berlangsung sejak zaman penjajahan kolonial Belanda. Kemudian berlanjut saat Jepang berhasil mengalahkan Belanda dan menguasai Indonesia. Tak lama berselang Belanda berhasil merebut kembali Indonesia sebagai tanah jajahan dari pendudukan Jepang dan kembali menguasai lahan-lahan yang ada di Kelurahan Tanjung Tongah. Meski demikian, pada kedatangan yang kedua, Belanda sudah membiarkan masyarakat pribumi mengelola lahan-lahan yang sudah ditanami berbagai tanaman. Setelah Indonesia merdeka polemik terkait lahan yang ada di Kelurahan Tanjung Tongah kembali bergejolak pada masa Orde Baru. Di mana seperti penuturan Bapak Kestiono sebelumnya, pada rezim Orde Baru tersebut masyarakat yang mengelola lahan di Tanjung Tongah dipaksa menyerahkan lahannya untuk pemerintah dan masyarakat dijadikan buruh pada lahannya sendiri.

Setelah sejarah konflik lahan yang begitu panjang, dewasa ini pergolakan terkait alih fungsi lahan di Kelurahan Tanjung Tongah memulai babak baru. Hal ini dipicu pembangunan perumahan di lahan tersebut yang diperuntukkan bagi masyarakat manapun yang ingin tinggal di sana dengan cara membeli rumah yang sudah dibangun tersebut. Pembangunan perumahan di atas lahan yang berada di Tanjung Tongah ini merupakan program pemerintah untuk menjadikan Kota 
Pematangsiantar sebagai salah satu kota yang lebih maju dan moderen dengan hunian yang lebih relevan. Masyarakat yang selama ini menggarap lahan di Tanjung Tongah itu mulai khawatir akan kehilangan hak pakai lahan tersebut. Berbagai hal yang tersebut di atas merupakan salah satu sebab yang melatarbelakangi terjadinya gentrifikasi lahan yang ada di Kelurahan Tanjung Tongah saat ini.

Kepemilikan lahan di Kelurahan Tanjung Tongah oleh masyarakat memang tidak begitu jelas dan lemah secara hukum negara. Masyarakat bersikukuh atas kepemilikan lahan tersebut, tetapi negara dengan segala kuasanya memiliki semua kekuatan untuk mengusir masyarakat yang ada di sana jika sewaktu-waktu memerlukan lahan tersebut untuk digunakan sebagai salah satu instrument pembangunan dan perkembangan Kota Pematangsiantar dengan dalih pemanfaatan lahan. Dalam posisi inilah benih-benih konflik baru akan muncul akibat perlawanan masyarakat yang disebabkan oleh alih fungsi lahan yang sewaktu-waktu dilakukan pemerintah. Meski demikian, alih fungsi lahan sudah mulai dilakukan saat ini, di mana lahan yang berada di Kelurahan Tanjung Tongah mulai digarap untuk membangun perumahan dan sarana prasarana lainnya yang menunjang pembangunan di kawasan tersebut. Alih fungsi lahan itu mendapat respon dari masyarakat yang selama ini menggarap lahan tersebut.

Berdasarkan wawancara yang didapat, disimpulkan bahwa sebagian masyarakat yang menggarap lahan di Kelurahan Tanjung Tongah bukan pemilik asli dari tanah tersebut. Lahan-lahan yang ada di Tanjung Tongah tersebut mereka sewa dari para pemilik tanah atau tauke untuk digarap. Tanah-tanah tersebut milik para tuan tanah dan mereka menyewakan tanahnya agar menghasilkan. Menurut penuturan $\mathrm{Bu}$ Mesiem, para petani yang menyewa lahan tersebut nantinya akan membayar pemilik tanah dengan hasil tanaman yang mereka tanami. Pada tanahtanah tersebut ditanami berbagai tanaman, mulai dari tanaman palawija hingga padi.

Dengan segala fakta yang ada di lapangan, maka dapat diambil kesimpulan bahwa ada beberapa hal yang melatarbelakangi terjadinya Gentrifikasi dan alih fungsi lahan di Kelurahan Tanjung Tongah, Kota Pematangsiantar. Pertama, selain kepemilikan tanah oleh masyarakat yang tidak jelas dan tidak memiliki sertifikat 
yang diakui negara hingga kemudian masyarakat memilih menjual tanah tersebut. Kedua, dikarenakan tanah-tanah yang ada di Kelurahan Tanjung Tongah tersebut dimiliki oleh sebagian orang saja. Sehingga penggunaan tanah tersebut mutlak berada di tangan mereka, bukan di tangan masyarakat yang menyewa dan menggarap tanah itu.

\section{Pengaturan Tata Ruang Wilayah di Tanjung Tongah}

Penataan ruang wilayah merupakan bagian penting dalam upaya memajukan pembangunan kota yang lebih komplek dan modern. Pada bagian ini penulis akan menjelaskan mengenai bagaimana ketetapan Rancangan Tata Ruang Wilayah (RTRW) Kelurahan Tanjung Tongah secara khusus.

Tabel 3

Rencana Tata Ruang Wilayah yang Ditujukan Pada Kelurahan Tanjung Tongah

Tahun 2013-2032

\begin{tabular}{|c|c|c|c|}
\hline No. & Penggunaan & Meliputi & Gambaran Fisik \\
\hline 1. & $\begin{array}{l}\text { Sebagai Kawasan } \\
\text { Peruntukan Industri, } \\
\text { Pasal } 52 \text { Ayat } 2\end{array}$ & $\begin{array}{l}\text { Kegiatan peruntukan industri besar } \\
\text { seluas lebih kurang } 220,86 \text { hektare } \\
\text { yang meliputi } \\
\text { - Kelurahan Tanjung Tongah } \\
\text { - Kelurahan Tanjung Pinggir } \\
\text { - Kelurahan Naga Pitu } \\
\text { - Kelurahan Siopat Suhu }\end{array}$ & \\
\hline 2. & \begin{tabular}{|c|} 
Sebagai Kawasan \\
Peruntukan Pertanian \\
Pasal 55 Ayat 1,2 , dan
\end{tabular} & $\begin{array}{l}\text { a. Kawasan pertanian pangan (lahan } \\
\text { basah)seluas } 1.945 \text { ha } \\
\text { b. Kawasan peruntukan hortikultura } \\
\text { c. Kawasan pertanian perkebunan }\end{array}$ & \\
\hline 3. & $\begin{array}{l}\text { Sebagai Kawasan } \\
\text { Strategis Ekonomi } \\
\text { Pasal } 62 \text { ayat } 1\end{array}$ & $\begin{array}{l}\text { a. Rencana pengembangan } \\
\text { kawasan strategis ekonomi } \\
\text { agropolitan dataran tinggi. }\end{array}$ & \\
\hline 4. & \begin{tabular}{|} 
Sebagai Sistem Pusat \\
Pelayanan Kota Pasal \\
ayat 3
\end{tabular} & $\begin{array}{l}\text { a. Pusat perdagangan skala kota } \\
\text { b. Simpul transportasi regional } \\
\text { c. Pendidikan menengah } \\
\text { d. Pelayanan kesehatan } \\
\text { e. Perumahan penduduk rendah- } \\
\text { sedang }\end{array}$ & \\
\hline 5 . & $\begin{array}{c}\text { Sebagai Rencana } \\
\text { Sistem Jaringan } \\
\text { Transportasi Pasal } 12 \\
\text { ayat } 2\end{array}$ & $\begin{array}{l}\text { a. Terminal penumpang Tipe A } \\
\text { Sarantama di Kelurahan Tanjung } \\
\text { Tongah Kecamatan Siantar Martoba }\end{array}$ & \\
\hline
\end{tabular}

Sumber : Perda Nomor 1 Tahun 2013 Kota Pematangsianr

Dari data yang terdapat di dalam tabel tersebut menunjukkan bahwa rencana tata ruang wilayah di Kelurahan Tanjung Tongah lebih terfokus dan di 
dominasi menjadi kawasan yang diperuntukan untuk pertanian dan sekaligus menjadi kawasan strategis ekonomi agropolitan atau sebagai salah satu kawasan pelayanan bidang usahan pertanian di Kota Pemantangsiantar. Dengan beberapa fasilitas publik seperti terminal penumpang tipe A sebagai sistem jaringan transportasi dan beberapa di tujukan sebagai pusat pelayanan kota yang bergerak di bidang perdagangan dan jasa, dengan memiliki intensitas perumahan rendahsedang .

Namun jika dibandingkan dengan kondisi yang ada di Kelurahan Tanjung Tongah saat ini, rasanya apa yang telah direncanakan di dalam RTRW belum menempatkan pertanian seutuhnya menjadi komoditi utama dalam usahan pengembangan wilayahnya, karena pada fakta yang penulis temui di lapangan bahwa keadaan yang terjadi adalah di mana lahan pertanian menjadi semakin berkurang dan alih fungsi lahan pertanian menjadi perumahan semakin terlihat di sana, hal tersebut sejalan dengan hasil observasi penulis yang mencatat bahwa sudah ada 2 bangunan komplek perumahan dan ada 2 lahan pertanian yang telah di ratakan dan akan di jadikan bangunan perumahan dengan sekolah khusus Keagamaan di sana. Dari sini terlihat bahwa geliat fenomena Gentrifikasi mulai menyebar di Kelurahan Tanjung Tongah, apabila Pemerintah kurang konsisten dengan rancangan yang mereka buat, artinya akan semakin mendorong para pengembang/developer untuk giat mengalihkan fungsi lahan pertanian di Kelurahan Tanjung Tongah.

\section{Kesimpulan}

Ada beberapa hal yang melatarbelakangi terjadinya gentrifikasi atau alih fungsi lahan di Kelurahan Tanjung Tongah, Kecamatan Siantar Martoba, Kota Pematangsiantar, yaitu:

a. Status kepemilikan lahan yang yang tidak jelas. Sebagian masyarakat yang selama ini menggarap lahan-lahan di Kelurahan Tanjung Tongah tidak memiliki kelengakapan surat kepemilikan yang diakui negara, sehingga ketika ada pihak-pihak yang ingin membeli lahan mereka untuk dialihfungsikan, masyarakat lebih memilih menjual lahan tersebut. Selama ini beberapa masyarakat yang menggarap lahan di Kelurahan 
Tanjung Tongah hanya berdasarkan klaim bahwasanya tanah tersebut adalah pemberian dari perkebunan pada masa konflik Orde Baru.

b. Faktor pembangunan Kota dan Urbanisasi. Kedua faktor ini juga alasan di balik terjadinya alih fungsi lahan di Kelurahan Tanjung Tongah. Sebagai daerah pinggiran kota, daerah Tanjung Tongah ini menjadi salah satu lokasi pembangunan yang sudah bertujuan untuk menampung masyarakat yang melakukan urbanisasi ke pusat Kota Pematangsiantar. Oleh sebab itu, daerah Kelurahan Tanjung Tongah menjadi salah satu daerah yang dilaksanakn alih fungsi lahan.

c. Faktor gejolak ekonomi. Selain kepemilikan yang tidak jelas, masyarakat yang selama ini menggarap lahnnya di Kelurahan Tanjung Tongah menjual lahannya disebabkan oleh faktor ekonomi. Ketika ada pembeli yang mempu menawarka lahan mereka dengan harga ekonomis, maka mereka pun menjualnya, sehingga dengan demikian alih fungsi lahan di daerah tersebut terjadi. 


\section{Daftar Pustaka}

Badan Pusat Statistik Pematangsiantar, 2018. Statistik Luas Lahan Pertanian Pematangsiantar 2017.

Cristi Carolina, Linda, Implementasi Kebijakan Alih Fungsi Lahan Pertanian Menjadi Kawasan Perumahan. Jurnal Administrasi Publik (JAP), Vol. 2, No. 2, hlm (224229).

Dyayadi, 2005. Tata Kota Menurut Islam. Semarang : Khalifa.

Gumay Febrianto, Indra, 2015. Aktor Dan Relasi Kekuasaan Dalam Pengelolaan Mangrove Di Kabupaten Pesawaran, Provinsi Lampung, Indonesia. Jurnal Analisis Kebijakan Kehutanan Vol. 12 No. 2, Agustus 2015, hlm. 125 - 142.

Moleong, Lexy J. 2014. Metodologi Penelitian Kualitatif, Bandung : PT. Remaja Rosdakarya.

Musiyam, Muhammad. 2018. Mengkaji Teori RCP dalam Konteks Indonesia. http://journals.ums.ac.id/index.php/fg/article/view/514. Diakses 10 November 2018.

Nur Medha, Aska, 2017. Pandangan Terhadap Fenomena Gentrifikasi dan Hubungannya dengan Perencanaan Spasial. Jurnal Teknik ITS Vol. 6. No. 2

P.P.A, Pangeran, 2006. Senarai Antropologi Perkotaan dalam Jurnal Antropologi Perkotaan, Materi Ajar Antropologi Perkotaan.

Spradley, James, 1997. Metode Etnografi. Yogyakarta : PT. Wacana.

Tri Prayoga, I Nyoman, 2013. Keberlangsungan Menetap Penduduk Asli pada Kawasan di Sekitar Kampus UNDIP Tembalang sebagai Permukiman Kota Semarang yang Tergentrifikasi, Jurnal Pembangunan Wilayah dan Kota, Vol 9, No.1 